\title{
$\mathrm{ACM}$ 의 Rat를 이용한 13 주 반복 경구투여 독성시험 및 4 주 회복시험
}

\author{
박대명, 이상룡, 임종순*, 김승형 $\dagger$, 정인철
}

대전대학교 한의과대학 신경정신과학교실, 대전대학교 한의과대학 생명예방과학교실*, 대전대학교 동서생명과학연구원 $\dagger$

\section{A Thirteen Week Repeated Oral Dose Toxicity Test and A Four Week Recovery Test of ACM(Added Chongmyung-tang) in Sprague-Dawley Rats}

Dae-Myung Park, Sang-Ryong Lee, Jong-Soon Lim*, Seung-Hyung Kim†, In-Chul Jung

Dept. of Neuropsychiatry, College of Oriental Medicine, Daejeon University, Daejeon, Korea Dept. of Life Science and Preventative Medicine College of Oriental Medicine, DaeJeon University* Institute of Traditional Medicine and Bioscience, DaeJeon University +

\section{Abstract}

\section{Objectives :}

To provide information on the safety of ACM, we carried out a 13-week repeated oral dose toxicity and a 4-week recovery test of ACM in Sprague-Dawley rats.

\section{Methods :}

Female and male rats were treated with ACM with oral doses of 800,2000 , and $5000 \mathrm{mg} / \mathrm{kg}$. The ACM was administered for 13 weeks. Mortality, clinical signs, body weight changes, food consumption, ophthalmologic findings, urinalysis, hematological and biochemical parameters, gross findings, organ weights and histological markers were monitored during the study period. Moreover, the rats were monitored for 4 extra weeks to determine recovery time after the study period.

\section{Results :}

We found no mortality and no abnormalities in clinical signs, body weight, food consumption, ophthalmologic findings, urinalysis, hematological and biochemical parameters, gross findings, organ weights and histological markers in any of the rats tested.

\section{Conclusions :}

The no-observed adverse effects level (NOAEL) was considered as over $5000 \mathrm{mg} / \mathrm{kg}$ for male and female rats.

\section{Key Words :}

ACM, Added Chongmyung-Tang, 13 week repeated oral dose toxicity test, 4 week recovery test, SD rats.

Received : August 17, 2012; Revised : September 13, 2012; Accepted : September 13, 2012

Correspondence : In-Chul Jung, Address : Daejon Univ. College of Oriental Medicine, Yongun-dong, Dong-gu, Daejeon, Korea. Tel : +82-42-470-9129, Fax : +82-42-470-9006, E-mail : npjeong@dju.ac.kr

* This study was supported by agrant of the Traditional Korean Medicine R\&D Project, Ministry of Health \& Welfare, Republic of Korea. (Task-specific number: B090020). 


\section{I. 서론}

알츠하이머병(Alzheimer's Disease; AD)은 대 표적인 퇴행성 신경질환으로 노인성 치매를 야기 하며 지적 황폐화뿐만 아니라 행동 이상 및 인격 변화를 초래하게 되는 상태이다 ${ }^{1)}$. 노인반점 (senile plaques)과 신경섬유덩어리(neurofibrillary tangle)가 병리학적 특징으로 나타나며 ${ }^{2}$ 원인으 로 $\beta$-amyloid $(\beta \mathrm{A})$ 로 유발된 신경독성하과 산화적 손상 ${ }^{4)}$, 콜린성 신경원의 소실 ${ }^{5)}$ 등이 제시된다. $\mathrm{AD}$ 는 60 세 이후로는 나이가 듦에 따라 발생 빈 도가 점진적으로 증가하므로 노인 인구가 증가하 고 있는 나라에서는 중대한 의료, 사회 및 경제적 문제를 야기하고 있다 ${ }^{6)}$.

한의학에서 치매는 呆病, 健忘, 癲狂, 虛勞 등 에서 유사한 증상이 언급되고 주요 원인은 年老 體虛, 情志失調, 飲食失調, 中毒外傷이며 치법은 補益精氣, 補腎健脾, 豁痰化濁, 行氣活血, 清熱解 毒, 盆氣養血 등이다 ${ }^{1)}$.

$\mathrm{ACM}$ 은 聰明湯에 山査肉, 巴韩天을 가한 처방으로 聰明湯은 『東醫寶鑑』”에 “治多忘，久服能日誦千 言” 이라 기술되어 있고 이후 健忘 및 痴呆 병증 치료 에 사용되고 있으며 ${ }^{8)}$ 최근 聰明湯과 여러 聰明湯加味 方이 치매에 효과적인 치료제로 활용 될 수 있다는 다양한 연구 결과가 발표되었다 ${ }^{9-13)}$.

巴戟天은 補陽藥으로 분류되고 補腎陽, 壯筋 骨, 祛風濕하는 효능으로 陽瘘遺精, 宮冷不孕, 風 濕瘰痛, 腰膝酸軟 등을 치료하며 腎陽의 부족으 로 인한 제 증상에 활용되고 있고 ${ }^{14)}$, 김 ${ }^{15)}$ 등은 巴戟天이 항콜린작용과 아밀로이드 전구단백질 (amyloid precursor protein; APP)과 PS-1, PS-2 발현 억제능력을 보여 치매 치료에 활용될 수 있 다는 결과를 확인하였다.

山査肉은 行氣消食, 健脾開胃 하는 효능으로 食積不消, 脘腹脹滿을 치료하며 ${ }^{14)}$, 채 ${ }^{16)}$ 등은 山 查肉이 PC-12 cell의 IL-1ß, IL-6, APP, $\mathrm{AChE,gFAP} \mathrm{mRNA}$ 의 발현을 억제하고 microglial cell에서 IL- $1 \beta$, TNF- $a$ 의 발현과 ROS, NO의 생 성을 억제하여 치매의 치료에 활용될 수 있다고 보고하였다.

추가적인 연구를 통해 山查聰明湯과 巴戟天 聰明湯의 항염증효과, 기억력 감퇴 억제 효과, 뇌세포 보호효과, 행동개선효과가 확인되었고 17,18) 聰明湯에 巴戟天, 山查肉을 가한 聰明湯加 味方이 $\mathrm{BACE}$ 효소활성과 $\mathrm{BA}$ 의 과다 생성을 억 제하는 효과로 치매 치료에 효과가 있음이 확인 되었다 ${ }^{19)}$.

이에 본 연구팀은 현재까지 이루어진 聰明湯, 巴韩天, 山查肉 및 聰明湯에 巴韩天, 山查肉을 가 한 聰明湯加味方이 치매 치료에 효과적으로 활용 될 수 있다는 이전의 연구 결과를 바탕으로, 치매 치료 한방신약 개발의 일환으로 聰明湯에 巴戟 天, 山查肉을 가한 $\mathrm{ACM}$ 의 안정성에 대한 연구를 수행하였다. 본 연구에서는GLP기관에서 암수 Sprague-Dawley 랫드를 이용하여 ACM을 13 주 간 반복 경구투여 시 나타나는 독성반응과 그 안 정성을 평가하고, 4 주간의 회복군을 설정하여 독 성변화의 가역성 여부를 확인하였다.

\section{II. 방법}

\section{1. 시험기관}

시험의 전 과정을 GLP기관인 (주)바이오톡스 텍에서 진행하였다.

본 시험은 동물보호법에 근거한 (주)바이오톡 스텍의 동물실험윤리위원회에 의해 승인되었다 (승인번호 100208).

\section{2. 시험 동물 및 사육환경}

\section{1) 시험 동물}

본 시험에서는 $\mathrm{SPF}$ (specific pathogen-free) Sprague-Dawley계 랫드를 사용하였으며 Sprague- 
Dawley계 랫드는 의약품 등의 안전성시험에 널 리 사용되고 있으며, 비교할 기초자료가 풍부하 여 선택하였다. 입수 시에는 5주령 수컷 56마리, 111.4 132.4g, 5주령 암컷 56마리, 97.1 114.4g 이었으며 투여개시 시에는 6주령 수컷 50마리, 176.7 204.0g, 6주령 암컷 50마리, 140.8 170.4g 이었다. 반입 시 동물의 외관 검사, 체중 측정을 하였고 7 8일간의 순화기간 중 매일 1회 일반증 상을 관찰하였다. 순화기간 종료일에 일반증상 및 체중변화를 확인하여 모든 동물에 이상이 없 음을 확인하였다.

\section{2) 사육환경}

스테인리스 철망 사육상자 $(260 \mathrm{~W} \times 305 \mathrm{D} \times$ $210 \mathrm{H} \mathrm{mm}$ )에 검역, 순화기간 동안 2 3마리, 관찰 기간 동안 1마리를 사육하였다. 온도는 21.5 $23.5^{\circ} \mathrm{C}$, 상대습도 $34.9 \sim 65.5 \%$, 환기횟수 10 15회 /시간, 조명시간 12시간/일(오전 7시 오후 7시), 조도 150 300 Lux로 설정하였다. 사료는 실험동 물용 고형사료(Harlan Laboratories, Inc., USA)를 사용하였고 급이기에 고형사료를 넣어 자유섭취 시켰다. 음수는 청주시 수돗물을 필터유수살균기 로 여과한 후 자외선을 조사하였고, 자동급수장 치로 자유섭취 시켰다. 음수의 분석은 충청북도 보건환경연구원 '먹는물 수질기준 및 검사 등에 관한 규칙’ 의 전 항목에 대하여 실시하여 허용 범위 내에 속하는지를 확인하였다.

\section{3. 시험물질 및 투여}

\section{1) 시험물질}

본 실험에 사용한 $\mathrm{ACM}$ 은 (주)경방신약에서 표 준화하여 공급받았으며 전자저울(CP323S, Sartorius, germany)로 칭량하여 용기에 넣고 일부의 부형 제를 가한 후 균질화기(ARE-250, THINKY, Japan)를 이용하여 현탁시켰다. 조제병에 조제물 을 옮긴 후 부형제를 가하여 규정농도 $(80,200$, $500 \mathrm{mg} / \mathrm{m \ell}$ )로 조제하였다. 한 첩당 약재구성은 다음과 같다(Table 1).

\section{2) 투여절차}

시험물질의 임상적용 예상경로가 경구이므로 경구투여를 선택하였고, 투여액량은 $10 \mathrm{ml} / \mathrm{kg}$ 으 로 하였으며 개체별 투여액량은 매주 1 회의 측정 체중을 기준으로 산출하였다. 매일 오전에 경구 투여용 존데를 부착한 일회용 주사기 $(3,5,10$ $\mathrm{m} \ell)$ 를 이용하여 13 주간 1 일 1 회 위내에 강제투여 하였다.

\section{3) 군 분리 및 투여용량 설정}

군 분리는 순화 종료일에 실시하였고 평균 체 중에 가까운 암수 각 50 마리를 선발하였다. 선발 한 동물은 각 군 평균체중이 균등하도록 무작위 로 암수 각 4 군, 대조군 및 고용량군은 군당 15 마 리, 저용량군 및 중용량군은 군당 10 마리로 군 분 리 하였다(Table 2).

Table 1. Prescription of $\mathrm{ACM}($ Added Chonhmyung-Tang)

\begin{tabular}{ccc}
\hline Herb & Scientific Name & Amount $(\mathrm{g})$ \\
\hline 白茯神 & Poria cocos Walf & 4 \\
遠志 & Polygala tenuifolia & 2 \\
石菖蒲 & Acorigramineus Soland & 4 \\
巴载天 & Morinda officinalis & 2 \\
山査 & Crataegus pinnatifida & 2 \\
\hline Total & & 14 \\
\hline
\end{tabular}


Table 2. Composition of group

\begin{tabular}{ccccc}
\hline Group & $\begin{array}{c}\text { Dose } \\
(\mathrm{mg} / \mathrm{kg})\end{array}$ & $\begin{array}{c}\text { Administered fluid volume } \\
(\mathrm{ml} / \mathrm{kg})\end{array}$ & \multicolumn{2}{c}{ Number of animals(Objective numbers $)$} \\
\cline { 4 - 5 } G1 Controlgroup & 0 & 10 & $10(1101 \sim 1110)$ & $10(2101 \sim 2110)$ \\
& & 10 & $+5^{*}(1111 \sim 1115)$ & $+5^{*}(2111 \sim 2115)$ \\
G2 Low dosegroup & 800 & 10 & $10(1201 \sim 1210)$ & $10(2201 \sim 2210)$ \\
G3 Medium dosegroup & 2,000 & 10 & $10(1301 \sim 1310)$ & $10(2301 \sim 2310)$ \\
G4 High dosegroup & 5,000 & $10(1401 \sim 1410)$ & $10(2401 \sim 2410)$ \\
& & & $+5^{*}(1411 \sim 1415)$ & $+5^{*}(2411 \sim 2415)$ \\
\hline
\end{tabular}

*: Recoverygroup

반복투여 용량결정시험(Biotoxtech Study No.: M09008) 결과 $5,000 \mathrm{mg} / \mathrm{kg}$ 용량에서 시험물질 투 여에 기인한 독성변화가 관찰되지 않았다. 따라서 임상적용 예정용량(약 $3,181 \mathrm{mg} / \mathrm{human} / \mathrm{day}$, 성인 $60 \mathrm{~kg}$ 기준시 약 $53 \mathrm{mg} / \mathrm{kg}$ )의 약 94 배인 5,000 $\mathrm{mg} / \mathrm{kg}$ 을 고용량으로 설정하고, 공비 2.5 를 적용 하여 2,000 및 $800 \mathrm{mg} / \mathrm{kg}$ 을 각각 중용량 및 저용 량의 투여용량으로 설정하였다. 대조군에는 부형 제인 주사용수를 투여하였다.

\section{4. 관찰 및 검사}

이하의 관찰, 측정 및 검사일은 투여 개시일을 0 일로 하여, 투여 개시일로부터 7일간을 투여 1 주 로 계산하고, 회복 개시(투여 종료 후 익일)부터 7일간을 회복 1주로 하였다.

\section{1) 일반증상 관찰}

모든 동물에 대하여 1 일 1 회 일반증상을 관찰 하고, 1 일 2회 빈사 및 사망동물의 유무를 확인하 였다. 관찰은 투여 기간 동안 모든 동물에 대하여 투여 0 일부터 13 주간 실시하고, 13 주간의 투여 종료 후 회복군에 대하여 4주간 실시하였다.

\section{2) 체중 측정}

모든 동물에 대하여, 투여 개시일(투여 전), 투 여 개시 후 및 회복기간에 주 1 회, 부검일에 체중
을 측정하였다. 부검일의 체중은 절식을 실시하 였으므로 체중 평가에서 제외하였다. 회복군의 경우 투여 종료 후 익일 체중을 측정하였다.

\section{3) 사료섭취량 측정}

투여 개시 전의 사료섭취량은 군 분리 일로부 터 투여 개시 일까지 1 일간의 섭취량을 측정하였 다. 관찰기간(투여기간 및 회복기간)에는 7일간 의 섭취량을 측정하여 1 일의 평균 섭취량을 산출 하였다. 투여 13 주 및 회복 4주째에는 6일간의 섭취량을 측정하여 1 일의 평균 섭취량을 산출하 였다.

\section{4) 안과학적 검사}

주시험군은 각 군당 5 마리에 대하여 투여 13 주 에, 회복군 모든 동물에 대하여 회복 4주에 실시 하였다. 안과학적 검사는 산동제(Ocutropic ophthalmic drops, Samil pharma. Co., Ltd., Lot No. 019196, Korea)를 점안한 후, 육안 및 검안경 (ALL PUPIL IL, Keeler, U.K)으로 전안부, 중간투 광체, 안저에 대해서 실시하였다.

\section{5) 뇨검사}

주시험군은 각 군당 5 마리에 대하여 투여 13 주 에, 회복군 모든 동물에 대하여 회복 4 주에 뇨검 사를 실시하였다. 신선뇨(배설 후 약 3 시간 이내 
의 뇨) 및 축뇨(배설 후 약 24시간 뇨)를 수거하 여 검사를 실시하였다. 신선뇨 채취 중에는 투여 및 사료급여를 실시하지 않고 음수는 자유섭취 시켰다. 검사항목은 $\mathrm{pH}$, protein,glucose, ketone body, bilirubin, occult blood, 색상 및 투명도, 침사, 뇨량, 뇨비중 등이다.

\section{6) 혈액학적 검사}

모든 동물에 대하여 부검 전 약 18시간 이상 절식시킨 후 부검일에 isoflurane으로 마취하여 배대동맥으로부터 혈액을 채취하였다. 혈액학적 검사는 채취한 혈액 약 $1 \mathrm{~m} \ell$ 를 EDTA 함유 tube 에 넣은 후 혈구 분석기(ADVIA 120, SIEMENS, germany)로 측정하였다. 응고검사는 채취한 혈 액 약 2 ml를 3.2\% sodium citrate 함유 tube에 넣고 $3,000 \mathrm{rpm}$ 으로 10 분간 원심분리한 후 혈장 을 채취하였다. 응고시간 분석기(ACL 7000, Instrumentation Laboratory, U.S.A)로 측정하였 다. 검사항목은 $\mathrm{RBC}, \mathrm{HGB}, \mathrm{HCT}, \mathrm{MCV}, \mathrm{MCH}$, MCHC, PLT, WBC, WBC differential counting, reticulocytes, PT, APTT 등이다.

\section{7) 혈액생화학적 검사}

혈액생화학적 검사는 배대동맥에서 채취한 혈 액 중 혈액학적 검사용 혈액을 제외한 나머지 혈 액을 $3,000 \mathrm{rpm}$ 으로 10 분간 원심분리 후 혈청을 취하여 이용하였다. 혈액생화학 분석기(7080, HITACHI, Japan) 및 전해질 분석기(AVL9181, Roche,germany)로 측정하였다. 검사 항목은 ALT, AST, ALP,gGT, BUN, Crea, T-Bili, TP, Alb, A/G ratio, T-chol, TG, P,glu, Ca, Cl, Na, $\mathrm{K}$ 등이다.

\section{8) 부검}

모든 동물에 대해서 전신의 장기, 조직에 대하 여 상세한 육안검사를 실시하였다.

\section{9) 장기중량 측정}

모든 동물에 대하여 뇌, 뇌하수체, 심장, 폐, 간, 비장, 신장, 부신, 고환, 전립선, 난소, 자궁에 대한 습중량을 측정하고 절식체중에 대한 상대장 기중량비를 산출하였다. 신장, 부신, 고환, 난소는 좌, 우를 합하여 무게를 측정하였다.

\section{0) 조직병리학적 검사}

부검을 실시한 모든 동물에 대하여 뇌, 뇌하수 체, 갑상선, 부갑상선, 흥선, 폐, 기관지, 기관, 심 장, 간, 비장, 신장, 부신, 타액선, 식도, 위, 십이 지장, 공장, 회장, 맹장, 결장, 직장, 췌장, 고환, 부고환, 전립선, 정낭, 난소, 자궁, 질, 방광, 악하 림프절, 장간막 림프절, 안구 및 하더리안선, 유 선, 피부, 골수(대퇴골 및 흥골), 혀, 척수, 육안소 견이 관찰된 장기, 조직(피부, 꼬리)의 장기, 조직 을 적출하여 $10 \%$ 중성완충 포르말린용액(neutral buffered formalin)에 고정하고, 그 중 고환 및 안 구는 Davidson 고정액에 고정하였다.

고정한 장기, 조직은 삭정, 탈수 및 파라핀 포 매 등의 일반적인 조직처리과정을 거쳐 조직절편 을 제작하여 박절한 후, Hematoxylin \& Eosin 염 색을 실시하였다. 골조직은 Calci-Clear-Rapid ${ }^{\mathrm{TM}}$ 액(National diagnostics, U.S.A)을 사용하여 탈회 하였다. 잔여 장기, 조직은 $10 \%$ 중성완충 포르말 린용액에 보존하였다.

조직병리학적 검사는 대조군과 고용량군의 모 든 개체, 중용량군과 저용량군의 육안소견이 관 찰된 장기 및 조직(수컷 $2,000 \mathrm{mg} / \mathrm{kg}$ 투여군의 고 환, 암컷 $800 \mathrm{mg} / \mathrm{kg}$ 투여군의 피부, 암컷 2,000 $\mathrm{mg} / \mathrm{kg}$ 투여군의 자궁), 고용량군에서 시험물질에 의한 영향으로 사료되는 변화가 관찰된 경우, 중 용량 및 저용량군의 해당 장기, 조직(암컷 난소) 에 대하여 검경하였다. 


\section{1) 자료의 통계처리}

실험에서 얻어진 체중, 사료섭취량, 뇨량, 혈액 학적 검사, 혈액생화학적 검사, 장기중량 결과는 SAS(version 9.1.3, SAS Institute Inc., U.S.A)를 사용하여 검정하였다.

투여기간 및 주시험군의 측정치에 대해서 Bartlett test를 실시하여 유의수준 5\%에서 등분산 성을 검정하였다. 등분산성인 경우 One-way analysis of variance(ANOVA)를 실시하여 유의수 준 5\%에서 유의성이 관찰되면 Dunnett's t-test의 다중검정을 실시하였다(유의수준 : 양측 $5 \%$ 및 $1 \%)$. 등분산성이 기각되면 Kruskal-Wallis test를 실시하여 유의수준 5\%에서 유의성이 관찰되면 Steel' s test의 다중검정을 실시하였다(유의수준 : 양측 $5 \%$ 및 $1 \%)$.

회복군의 측정치에 대해서, Folded-F 검정법을 사용하여 등분산성을 유의수준 5\%에서 검정하였 다. 등분산성인 경우 Student t-test를, 등분산성이 기각되면 Aspin-Welch t-test를 실시하여 유의성 을 확인하였다(유의수준 : 양측 5\% 및 $1 \%$ ).

\section{III. 결과}

\section{1. 일반 증상}

관찰기간동안, 암수 대조군 및 시험물질투여군 에서 사망례는 관찰되지 않았다.

약물혼입변(compound-colored stool)이 800 $\mathrm{mg} / \mathrm{kg}$ 투여군에서 수컷은 투여 1 4일부터, 암컷 은 1 5일부터 투여기간동안 모든 동물에서 관찰 되었고, $2,000 \mathrm{mg} / \mathrm{kg}$ 및 $5,000 \mathrm{mg} / \mathrm{kg}$ 투여군은 모 든 동물에서 투여 1 일부터 투여기간동안 관찰되 었다. 회복군 암수 $5,000 \mathrm{mg} / \mathrm{kg}$ 투여군에서 약물 혼입변이 수컷은 투여 93일(회복 3일)까지, 암컷 은 투여 92일(회복 2일)까지 관찰된 후 회복되었 다. 따라서 약물혼입변은 투여기간동안 관찰되는 증상으로 시험물질 배설에 따른 착색변으로 판단 되어, 시험물질의 독성변화는 아닌 것으로 사료 된다. 그 외, 투여기간동안, 수컷 대조군 1 마리에 서 전지에 상처(wound) 및 가피형성(crust formation)이 관찰되었고, $800 \mathrm{mg} / \mathrm{kg}$ 투여군의 1마

Table 3. Summary of Clinical Signs

\begin{tabular}{cccc}
\hline Sex : Male & & & \\
\hline Group / Dose $(\mathrm{mg} / \mathrm{kg})$ & No. of animals & Clinical signs & No. of animals affected \\
\hline G1 / & 15 & Wound(left forelimb) & 1 \\
\cline { 3 - 4 } G2 / 800 & 10 & Compound-colored stool & 10 \\
\hline G3 / 2,000 & 10 & Coss of teeth(upper teeth) & 1 \\
\hline G4/5,000 & 15 & Compound-colored stool & 10 \\
\hline Sex : Female & & Loss of teeth(upper teeth) & 1 \\
\hline G1 / & 15 & Compound-colored stool & 10 \\
\hline G2 / 8,00 & 10 & Mass(left shoulder) & 1 \\
\hline G3 / 2,000 & 10 & Compound-colored stool & 10 \\
\hline G4 / 5,000 & 15 & Bloody stool & 1 \\
\hline
\end{tabular}


Table 4. Summary of Clinical Signs (Recovery period)

\begin{tabular}{cccc}
\hline Sex : Male & & & \\
\hline Group $/$ Dose $(\mathrm{mg} / \mathrm{kg})$ & No. of animals & Clinical signs & No. of animals affected \\
\hline G4 $/ 5,000$ & 5 & Compound-colored stool & 5 \\
\hline Sex $:$ Female & & & \\
\hline G1 $/ 0$ & 5 & Exfoliation(tail) & 1 \\
\hline G4 $/ 5,000$ & 5 & Compound-colored stool & 5 \\
\hline
\end{tabular}

리에서 이의 결손(loss of teeth)이 관찰되었다. 암컷 대조군 1 마리에서 이의 결손이 관찰되었고, $800 \mathrm{mg} / \mathrm{kg}$ 투여군의 1마리에서 좌측 겨드랑이에 종양(mass)이 투여 70일부터 관찰되었으며 2,000 $\mathrm{mg} / \mathrm{kg}$ 투여군의 1마리에서 혈변(bloody stool)이 투여 36, 37 및 39일에 관찰되었다. 회복기간 동 안, 암컷 대조군 1 마리에서 꼬리에 표피박리 (exfoliation)가 투여 93일부터 관찰되었다. 이러 한 증상은 일시적으로 관찰되거나, 1 마리씩만 관 찰되어 시험물질 투여에 기인한 영향은 아닌 것 으로 사료된다(Table 3, 4).

\section{2. 체중 변화}

투여기간 동안 수컷 시험물질 투여군에서 대조 군과 비교 시 유의성 있는 체중변화는 관찰되지 않았다. 암컷 $5,000 \mathrm{mg} / \mathrm{kg}$ 투여군에서 투여 9 및 10 주에 대조군과 비교 시 유의성 있는 체중증가 가 관찰되었으나, 일시적인 것으로 시험물질에 의한 독성변화는 아닌 것으로 사료된다. 회복기 간 동안 암수 $5,000 \mathrm{mg} / \mathrm{kg}$ 투여군에서 대조군과 비교 시 유의성 있는 체중변화는 관찰되지 않았 다(Fig. 1, 2).

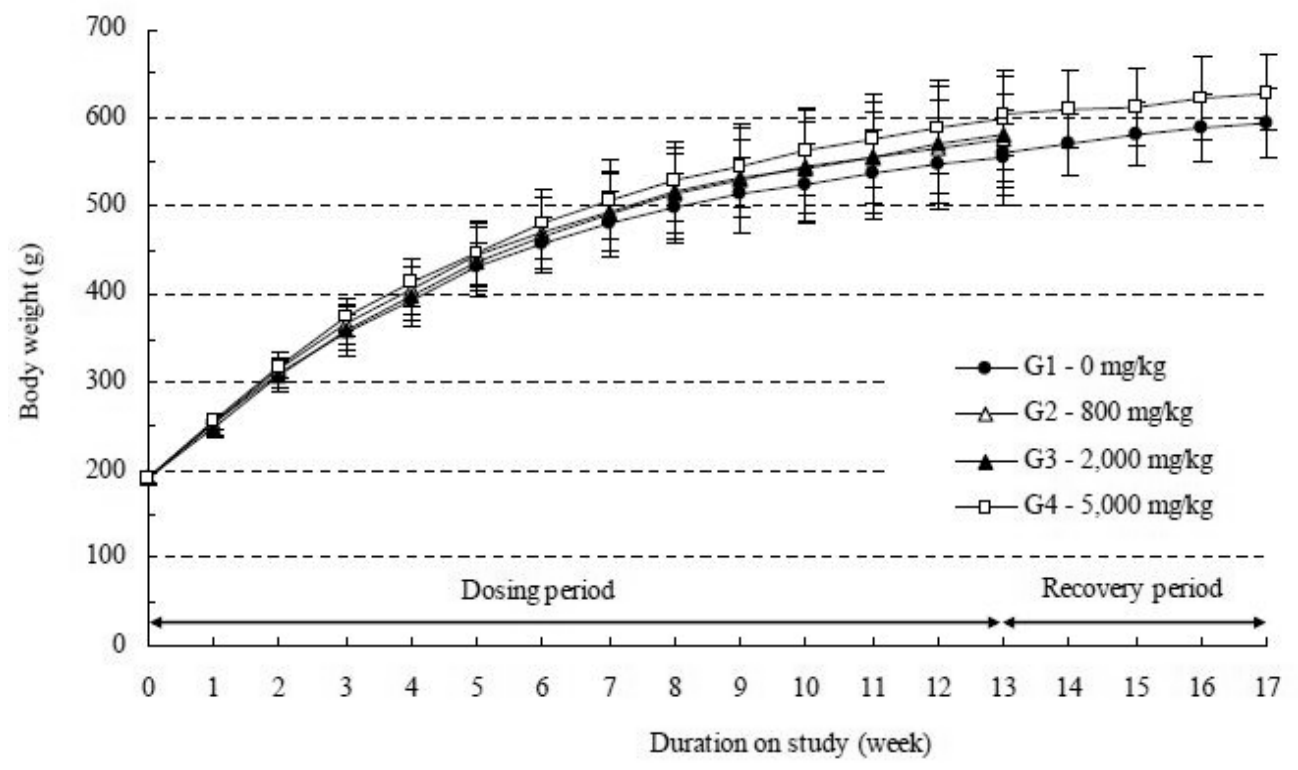

Fig. 1. Body Weights in Male SD Rats. 


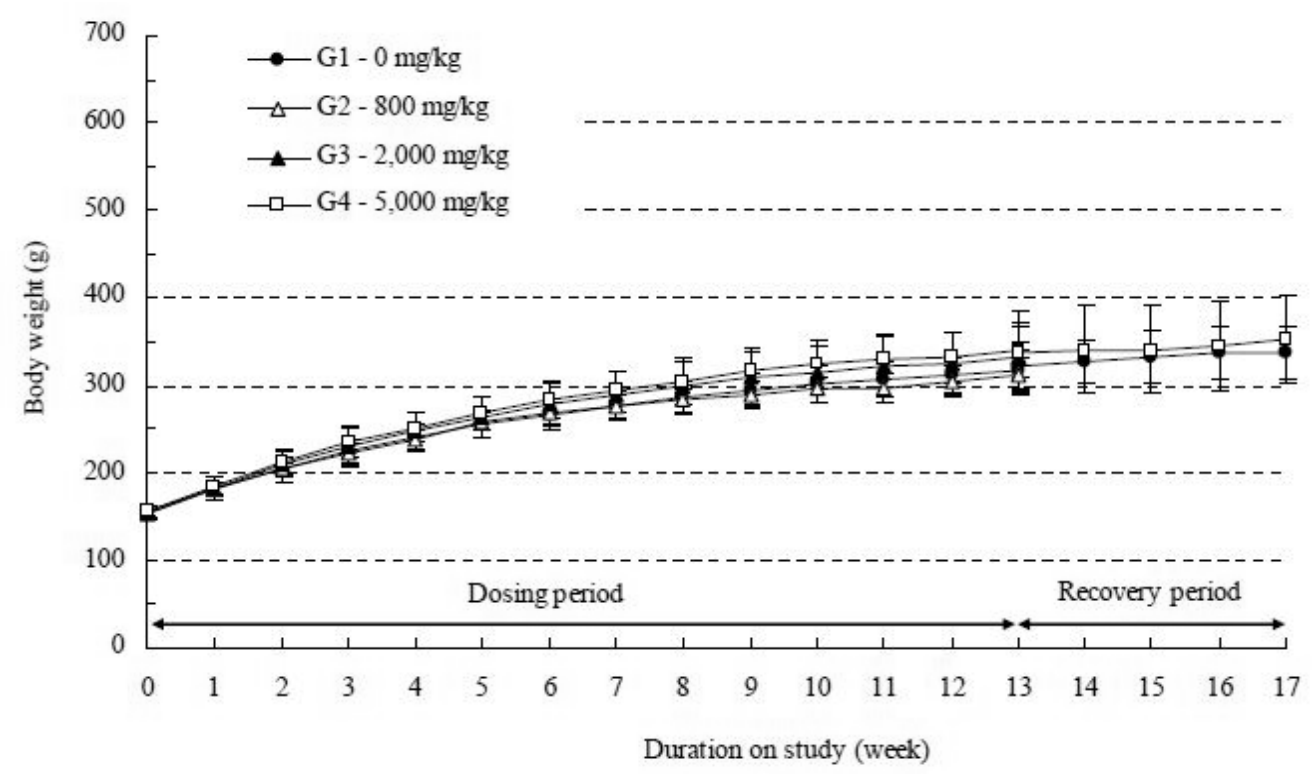

Fig. 2. Body Weights in Female SD Rats.

\section{3. 사료섭취량}

투여기간 동안, 암수 시험물질 투여군에서 대 조군과 비교 시 유의성 있는 사료섭취량 변화는 관찰되지 않았다. 회복기간 동안 암수 5,000 $\mathrm{mg} / \mathrm{kg}$ 투여군에서 대조군과 비교 시 유의성 있 는 사료섭취량 변화는 관찰되지 않았다.

\section{4. 안과학적 검사}

주시험군의 암수 시험물질 투여군과 회복군의 암수 $5,000 \mathrm{mg} / \mathrm{kg}$ 투여군에서 이상 소견은 관찰 되지 않았다.

\section{5. 뇨검사}

주시험군의 암수 시험물질 투여군에서 시험물 질에 의한 영향으로 판단되는 결과는 없었다. 그 외, 뇨의 투명도(transparency)의 변화, 뇨단백 (protein), 케톤체(ketone body)가 관찰되었으나, 모두 미량의 검출로서 용량의존성이 없거나 신장 의 형태학적 변화가 관찰되지 않았으므로 독성학
적 의미는 없다고 사료된다.

회복군의 암수 $5,000 \mathrm{mg} / \mathrm{kg}$ 투여군에서 시험물 질에 의한 영향으로 판단되는 결과는 없었다. 그 외, 수컷 $5,000 \mathrm{mg} / \mathrm{kg}$ 투여군에서 뇨량의 증가가 관찰되었으나 비교적 경미한 변동으로서, 주시험 군에서 시험물질에 의한 영향이 인정되지 않았으 며 신장의 형태학적인 변화도 관찰되지 않았으므 로 독성학적인 의미는 없다고 사료된다. 또한, 뇨 의 투명도의 변화, 뇨단백 및 케톤체가 관찰되었 으나 대조군에서도 관찰되었거나 신장의 형태학 적 변화가 관찰되지 않았으므로 독성학적 의미는 없다고 사료된다.

\section{6. 혈액학적 검사}

주시험군의 암수 시험물질 투여군에서 시험물 질에 의한 영향으로 판단되는 결과는 없었다. 수 컷 $800,2,000$ 및 $5,000 \mathrm{mg} / \mathrm{kg}$ 투여군 및 암컷 $5,000 \mathrm{mg} / \mathrm{kg}$ 투여군에서의 적혈구수 $(\mathrm{RBC})$ 의 감 소가 관찰되었으나 모두 경미한 변동으로서 망상 
Table 5. Summary of Hematological Parameters (Maingroup)

\begin{tabular}{|c|c|c|c|c|c|c|c|c|c|}
\hline \multicolumn{10}{|c|}{ Sex : Male } \\
\hline \multirow{2}{*}{ Group $(\mathrm{mg} / \mathrm{kg})$ Dose } & & \multirow{2}{*}{$\begin{array}{c}\mathrm{RBC} \\
\left(\mathrm{x} 10^{6} \text { cells } / \mu \mathrm{L}\right)\end{array}$} & \multirow{2}{*}{$\begin{array}{l}\text { HGB } \\
\text { (g/dL) }\end{array}$} & \multirow{2}{*}{$\begin{array}{c}\text { HCT } \\
(\%)\end{array}$} & \multicolumn{3}{|c|}{ RBC Indices } & \multirow{2}{*}{$\begin{array}{c}\text { PLT } \\
\left(\mathrm{x} 10^{3} \text { cells } / \mu \mathrm{L}\right)\end{array}$} & \multirow{2}{*}{$\begin{array}{l}\text { Reti } \\
(\%)\end{array}$} \\
\hline & & & & & MCV(fL) & $\mathrm{MCH}(\mathrm{pg})$ & $\operatorname{MCHC}(\mathrm{g} / \mathrm{dL})$ & & \\
\hline \multirow{3}{*}{$\begin{array}{c}\text { G1 } \\
0\end{array}$} & Mean & 9.12 & 15.3 & 45.8 & 50.3 & 16.8 & 33.4 & 1056 & 2.2 \\
\hline & S.D. & 0.29 & 0.4 & 1.3 & 1.3 & 0.5 & 0.4 & 107 & 0.4 \\
\hline & $\mathrm{N}$ & 10 & 10 & 10 & 10 & 10 & 10 & 10 & 10 \\
\hline \multirow{3}{*}{$\begin{array}{c}\text { G2 } \\
800\end{array}$} & Mean & $8.79 *$ & $14.6^{*}$ & $44.1^{*}$ & 50.2 & 16.7 & 33.2 & 1153 & 2.6 \\
\hline & S.D. & 0.26 & 0.5 & 1.1 & 1.8 & 0.8 & 0.5 & 163 & 0.5 \\
\hline & $\mathrm{N}$ & 10 & 10 & 10 & 10 & 10 & 10 & 10 & 10 \\
\hline \multirow{3}{*}{$\begin{array}{c}\mathrm{G} 3 \\
2,000\end{array}$} & Mean & $8.67^{* * * * *}$ & 15.0 & 44.9 & 51.8 & 17.3 & 33.4 & 1111 & 2.7 \\
\hline & S.D. & 0.32 & 0.6 & 1.7 & 1.2 & 0.5 & 0.7 & 117 & 0.3 \\
\hline & $\mathrm{N}$ & 10 & 10 & 10 & 10 & 10 & 10 & 10 & 10 \\
\hline \multirow{3}{*}{$\begin{array}{c}G 4 \\
5,000\end{array}$} & Mean & $8.71^{* * * *}$ & 14.8 & 44.4 & 51.0 & 17.0 & 33.4 & 1067 & 2.4 \\
\hline & S.D. & 0.19 & 0.5 & 1.3 & 1.5 & 0.6 & 0.4 & 126 & 0.4 \\
\hline & $\mathrm{N}$ & 10 & 10 & 10 & 10 & 10 & 10 & 10 & 10 \\
\hline \multirow{2}{*}{ Group / Dose } & & WBC & \multicolumn{5}{|c|}{ WBC Differential Counting(\%) } & $\mathrm{PT}$ & APTT \\
\hline & & $\left(\mathrm{x} 10^{3}\right.$ cells $\left./ \mu \mathrm{L}\right)$ & $\mathrm{NEU}$ & LYM & MONO & EOS & BASO & $(\mathrm{sec})$ & $(\mathrm{sec})$ \\
\hline \multirow{3}{*}{$\begin{array}{c}\text { G1 } \\
0\end{array}$} & Mean & 8.13 & 22.9 & 70.9 & 3.8 & 1.3 & 0.1 & 14.9 & 17.2 \\
\hline & S.D. & 1.37 & 9.7 & 9.7 & 0.7 & 0.3 & 0.0 & 0.5 & 1.1 \\
\hline & $\mathrm{N}$ & 10 & 10 & 10 & 10 & 10 & 10 & 10 & 10 \\
\hline & Mean & 9.17 & 20.6 & 74.5 & 2.9 & 1.3 & 0.2 & 14.8 & 16.3 \\
\hline $\begin{array}{l}\text { G2 } \\
800\end{array}$ & S.D. & 1.96 & 6.5 & 7.5 & 0.9 & 0.5 & 0.1 & 0.4 & 1.0 \\
\hline & $\mathrm{N}$ & 10 & 10 & 10 & 10 & 10 & 10 & 10 & 10 \\
\hline & Mean & 10.54 & 18.9 & 76.4 & $2.7^{*}$ & 1.3 & 0.2 & 14.5 & 15.5 \\
\hline $\begin{array}{c}\text { G3 } \\
2.000\end{array}$ & S.D. & 3.68 & 5.5 & 6.3 & 1.0 & 0.4 & 0.1 & 0.5 & 2.1 \\
\hline & $\mathrm{N}$ & 10 & 10 & 10 & 10 & 10 & 10 & 10 & 10 \\
\hline & Mean & 9.23 & 19.0 & 76.8 & $2.4^{* * *}$ & 1.1 & 0.2 & 14.8 & 15.8 \\
\hline $\begin{array}{c}\text { G4 } \\
5000\end{array}$ & S.D. & 1.13 & 6.9 & 7.2 & 0.6 & 0.3 & 0.1 & 0.6 & 2.0 \\
\hline & $\mathrm{N}$ & 10 & 10 & 10 & 10 & 10 & 10 & 10 & 10 \\
\hline & & & & Sex & Female & & & & \\
\hline & & $\mathrm{RBC}$ & HGB & HCT & & $\mathrm{RBC}$ Ind & & PLT & Reti \\
\hline$(\mathrm{mg} / \mathrm{kg})$ & & $\left(\mathrm{x} 10^{6}\right.$ cells $\left./ \mu \mathrm{L}\right)$ & $(\mathrm{g} / \mathrm{dL})$ & $(\%)$ & MCV(fL) & $\mathrm{MCH}(\mathrm{pg})$ & $\mathrm{MCHC}(\mathrm{g} / \mathrm{dL})$ & $\left(\mathrm{x} 10^{3}\right.$ cells $\left./ \mu \mathrm{L}\right)$ & $(\%)$ \\
\hline & Mean & 8.10 & 14.6 & 43.0 & 53.1 & 18.0 & 34.0 & 1082 & 2.0 \\
\hline $\begin{array}{c}\text { G1 } \\
0\end{array}$ & S.D. & 0.29 & 0.4 & 1.3 & 1.3 & 0.5 & 0.3 & 139 & 0.4 \\
\hline & $\mathrm{N}$ & 10 & 10 & 10 & 10 & 10 & 10 & 10 & 10 \\
\hline & Mean & 8.09 & 14.6 & 42.9 & 53.0 & 18.0 & 33.9 & 1071 & 2.1 \\
\hline $\begin{array}{l}G 2 \\
800\end{array}$ & S.D. & 0.31 & 0.5 & 1.7 & 1.5 & 0.5 & 0.5 & 76 & 0.3 \\
\hline & $\mathrm{N}$ & 10 & 10 & 10 & 10 & 10 & 10 & 10 & 10 \\
\hline & Mean & 7.85 & 14.2 & 41.9 & 53.5 & 18.2 & 34.0 & 1018 & 2.3 \\
\hline $\begin{array}{c}G 3 \\
2,000\end{array}$ & S.D. & 0.47 & 0.5 & 1.6 & 1.9 & 0.6 & 0.4 & 336 & 0.5 \\
\hline & $\mathrm{N}$ & 10 & 10 & 10 & 10 & 10 & 10 & 10 & 10 \\
\hline & Mean & $7.72^{*}$ & 14.3 & 41.9 & 54.3 & 18.5 & 34.1 & 1122 & 2.5 \\
\hline $\begin{array}{c}G 4 \\
5,000\end{array}$ & S.D. & 0.27 & 0.5 & 1.2 & 2.1 & 0.8 & 0.5 & 133 & 1.4 \\
\hline & $\mathrm{N}$ & 10 & 10 & 10 & 10 & 10 & 10 & 10 & 10 \\
\hline Group / Dose & & WBC & & WB & Different & al Counting & & PT & APTT \\
\hline$(\mathrm{mg} / \mathrm{kg})$ & & $\left(\mathrm{x} 10^{3}\right.$ cells $\left./ \mu \mathrm{L}\right)$ & NEU & LYM & MONO & EOS & BASO & $(\mathrm{sec})$ & (sec) \\
\hline & Mean & 4.21 & 15.8 & 79.4 & 2.2 & 2.0 & 0.2 & 14.5 & 14.3 \\
\hline $\begin{array}{c}\text { Gl } \\
0\end{array}$ & S.D. & 1.08 & 5.3 & 4.7 & 0.7 & 0.7 & 0.1 & 0.8 & 1.8 \\
\hline & $\mathrm{N}$ & 10 & 10 & 10 & 10 & 10 & 10 & 10 & 10 \\
\hline & Mean & 4.40 & 18.5 & 76.9 & 2.5 & 1.6 & 0.1 & 14.8 & 15.5 \\
\hline $\begin{array}{l}\text { G2 } \\
800\end{array}$ & S.D. & 1.94 & 5.9 & 6.8 & 1.1 & 0.6 & 0.1 & 0.5 & 0.8 \\
\hline & $\mathrm{N}$ & 10 & 10 & 10 & 10 & 10 & 10 & 10 & 10 \\
\hline & Mean & 4.24 & 18.6 & 77.1 & 2.1 & 1.6 & 0.1 & 15.0 & 15.6 \\
\hline $\begin{array}{c}\mathrm{G} 3 \\
2.000\end{array}$ & S.D. & 0.59 & 6.0 & 6.5 & 0.6 & 0.7 & 0.1 & 0.6 & 1.1 \\
\hline & $\mathrm{N}$ & 10 & 10 & 10 & 10 & 10 & 10 & 10 & 10 \\
\hline & Mean & 4.69 & 17.6 & 77.5 & 2.4 & 1.4 & 0.2 & 14.8 & 15.7 \\
\hline $\begin{array}{c}\text { G4 } \\
5,000\end{array}$ & S.D. & 1.33 & 6.9 & 7.3 & 0.9 & 0.3 & 0.1 & 0.6 & 1.6 \\
\hline & $\mathrm{N}$ & 10 & 10 & 10 & 10 & 10 & 10 & 10 & 10 \\
\hline
\end{tabular}

Significantly different from control by Dunnett's t-test : * $p<0.05, * *{ }^{*}<0.01$. 
적혈구수(Reti) 등 빈혈과 연관된 다른 적혈구 관 련 항목의 변동이 없고 비장 및 간에서 조혈과 관 련된 형태학적 변화가 관찰되지 않았으므로 독성 학적 의미는 없다고 사료된다.

수컷 2,000 및 $5,000 \mathrm{mg} / \mathrm{kg}$ 투여군에서의 백혈구 백분율중 단핵구 $(\mathrm{MONO})$ 의 감소가 관찰되었으 나 경미한 변동으로 총백혈구수(WBC)의 변동도
동반하지 않았으므로 독성학적 의미는 없다고 사 료된다. 그 외, 수컷 $800 \mathrm{mg} / \mathrm{kg}$ 투여군에서 혈색 소량(HGB) 및 헤마토크리트치(HCT)의 감소가 관찰되었으나 모두 경미한 변동으로서 용량의존 성이 없었으므로 독성학적 의미는 없다고 사료된 다(Table 5). 회복군의 암수 $5,000 \mathrm{mg} / \mathrm{kg}$ 투여군 에서 시험물질에 의한 영향으로 판단되는 결과는

Table 6. Summary of Hematological Parameters (Recoverygroup)

\begin{tabular}{|c|c|c|c|c|c|c|c|c|c|}
\hline \multicolumn{10}{|c|}{ Sex : Male } \\
\hline \multirow{2}{*}{$\begin{array}{c}\text { Group / } \\
\text { Dose (mg/kg) }\end{array}$} & & \multirow{2}{*}{$\left(\times 10^{6}{ }^{\mathrm{RBC}}\right.$ cells $\left./ \mu \mathrm{L}\right)$} & \multirow{2}{*}{$\begin{array}{l}\text { HGB } \\
(\mathrm{g} / \mathrm{dL})\end{array}$} & \multirow{2}{*}{$\begin{array}{c}\mathrm{HCT} \\
(\%)\end{array}$} & \multicolumn{3}{|c|}{ RBC Indices } & \multirow{2}{*}{$\begin{array}{c}\text { PLT } \\
\left(\times 10^{3} \text { cells } / \mu \mathrm{L}\right)\end{array}$} & \multirow{2}{*}{$\begin{array}{l}\text { Reti } \\
(\%)\end{array}$} \\
\hline & & & & & $\mathrm{MCV}(\mathrm{fL})$ & $\mathrm{MCH}(\mathrm{pg})$ & $\operatorname{MCHC}(\mathrm{g} / \mathrm{dL})$ & & \\
\hline \multirow{3}{*}{$\begin{array}{c}\text { G1 } \\
0\end{array}$} & Mean & 8.99 & 15.1 & 44.3 & 49.3 & 16.8 & 34.1 & 1107 & 2.3 \\
\hline & S.D. & 0.35 & 0.6 & 1.7 & 1.2 & 0.6 & 0.5 & 77 & 0.2 \\
\hline & $\mathrm{N}$ & 5 & 5 & 5 & 5 & 5 & 5 & 5 & 5 \\
\hline \multirow{3}{*}{$\begin{array}{c}\text { G4 } \\
5,000\end{array}$} & Mean & 8.56 & 14.8 & 42.9 & 50.2 & 17.3 & 34.4 & 1243 & 2.5 \\
\hline & S.D. & 0.33 & 0.4 & 1.4 & 0.7 & 0.5 & 0.8 & 326 & 0.5 \\
\hline & $\mathrm{N}$ & 5 & 5 & 5 & 5 & 5 & 5 & 5 & 5 \\
\hline \multirow{2}{*}{$\begin{array}{c}\text { Group / } \\
\text { Dose(mg/kg) }\end{array}$} & & \multirow{2}{*}{$\begin{array}{c}\text { WBC } \\
\left(\mathrm{x} 10^{3} \text { cells } / \mu \mathrm{L}\right)\end{array}$} & \multicolumn{5}{|c|}{ WBC Differential Counting(\%) } & \multirow{2}{*}{$\begin{array}{l}\text { PT } \\
(\mathrm{sec})\end{array}$} & \multirow{2}{*}{$\begin{array}{l}\text { APTT } \\
(\mathrm{sec})\end{array}$} \\
\hline & & & NEU & LYM & MONO & EOS & BASO & & \\
\hline \multirow{3}{*}{$\begin{array}{c}\text { G1 } \\
0\end{array}$} & Mean & 8.51 & 21.7 & 73.4 & 3.2 & 1.2 & 0.1 & 14.5 & 16.9 \\
\hline & S.D. & 1.52 & 8.9 & 9.7 & 1.1 & 0.4 & 0.1 & 0.4 & 0.9 \\
\hline & $\mathrm{N}$ & 5 & 5 & 5 & 5 & 5 & 5 & 5 & 5 \\
\hline \multirow{3}{*}{$\begin{array}{c}\mathrm{G} 4 \\
5,000\end{array}$} & Mean & 8.06 & 19.3 & 75.2 & 3.5 & 1.2 & 0.2 & 14.2 & $15.0^{*}$ \\
\hline & S.D. & 1.25 & 8.6 & 10.8 & 1.8 & 0.5 & 0.1 & 0.6 & 1.5 \\
\hline & $\mathrm{N}$ & 5 & 5 & 5 & 5 & 5 & 5 & 5 & 5 \\
\hline \multicolumn{10}{|c|}{ Sex : Female } \\
\hline \multirow{2}{*}{$\begin{array}{c}\text { Group / } \\
\text { Dose(mg/kg) }\end{array}$} & & \multirow{2}{*}{$\left(\times 10^{6}{ }^{\mathrm{RBC}}\right.$ cells $\left./ \mu \mathrm{L}\right)$} & \multirow{2}{*}{$\begin{array}{l}\text { HGB } \\
(\mathrm{g} / \mathrm{dL})\end{array}$} & \multirow{2}{*}{$\begin{array}{c}\mathrm{HCT} \\
(\%)\end{array}$} & \multicolumn{3}{|c|}{ RBC Indices } & \multirow{2}{*}{$\left(\mathrm{x} 10^{3} \stackrel{\text { PLT }}{\text { cells } / \mu \mathrm{L})}\right.$} & \multirow{2}{*}{$\begin{array}{l}\text { Reti } \\
(\%)\end{array}$} \\
\hline & & & & & $\mathrm{MCV}(\mathrm{fL})$ & $\mathrm{MCH}(\mathrm{pg})$ & $\mathrm{MCHC}(\mathrm{g} / \mathrm{dL})$ & & \\
\hline \multirow{3}{*}{$\begin{array}{c}\text { G1 } \\
0\end{array}$} & Mean & 7.52 & 13.8 & 40.5 & 54.0 & 18.4 & 34.1 & 1079 & 2.3 \\
\hline & S.D. & 0.26 & 0.4 & 0.8 & 2.4 & 0.9 & 0.5 & 155 & 0.7 \\
\hline & $\mathrm{N}$ & 5 & 5 & 5 & 5 & 5 & 5 & 5 & 5 \\
\hline \multirow{3}{*}{$\begin{array}{c}\text { G4 } \\
5,000\end{array}$} & Mean & 7.95 & 14.6 & 42.7 & 53.7 & 18.3 & 34.1 & 993 & 2.7 \\
\hline & S.D. & 0.48 & 0.9 & 3.0 & 1.0 & 0.3 & 0.3 & 121 & 0.6 \\
\hline & $\mathrm{N}$ & 5 & 5 & 5 & 5 & 5 & 5 & 5 & 5 \\
\hline Group / & & WBC & & WBC & Differenti & al Countins & $(\%)$ & PT & APTT \\
\hline $\operatorname{Dose}(\mathrm{mg} / \mathrm{kg})$ & & $\left(\mathrm{x} 10^{3}\right.$ cells $\left./ \mu \mathrm{L}\right)$ & $\mathrm{NEU}$ & LYM & MONO & EOS & BASO & $(\mathrm{sec})$ & (sec) \\
\hline & Mean & 4.98 & 18.3 & 76.9 & 2.5 & 1.4 & 0.2 & 14.3 & 14.5 \\
\hline $\begin{array}{c}\text { G1 } \\
0\end{array}$ & S.D. & 1.71 & 3.9 & 5.0 & 1.1 & 0.1 & 0.1 & 0.9 & 0.8 \\
\hline & $\mathrm{N}$ & 5 & 5 & 5 & 5 & 5 & 5 & 5 & 5 \\
\hline & Mean & 5.64 & 13.8 & 82.5 & 2.2 & $0.9^{* * *}$ & 0.1 & 14.3 & 14.5 \\
\hline $\begin{array}{c}\text { G4 } \\
5.000\end{array}$ & S.D. & 1.58 & 3.9 & 4.3 & 0.7 & 0.2 & 0.0 & 0.6 & 1.1 \\
\hline & $\mathrm{N}$ & 5 & 5 & 5 & 5 & 5 & 5 & 5 & 5 \\
\hline
\end{tabular}

Significantly different from control by Dunnett's t-test : * $p<0.05,{ }^{* * *} p<0.01$ 
Table 7. Summary of Clinical Chemistry (Maingroup)

\begin{tabular}{|c|c|c|c|c|c|c|c|c|c|c|}
\hline \multicolumn{11}{|c|}{ Sex : Male } \\
\hline $\begin{array}{c}\text { Group } / \\
\text { Dose(mg/kg) }\end{array}$ & & $\begin{array}{c}\text { ALT } \\
(\mathrm{U} / \mathrm{L})\end{array}$ & $\begin{array}{c}\text { AST } \\
(\mathrm{U} / \mathrm{L})\end{array}$ & $\begin{array}{c}\mathrm{ALP} \\
(\mathrm{U} / \mathrm{L})\end{array}$ & $\begin{array}{l}\text { GGT } \\
(\mathrm{U} / \mathrm{L})\end{array}$ & $\begin{array}{c}\text { Glu } \\
(\mathrm{mg} / \mathrm{dL})\end{array}$ & $\begin{array}{c}\text { BUN } \\
(\mathrm{mg} / \mathrm{dL})\end{array}$ & $\begin{array}{c}\text { Crea } \\
(\mathrm{mg} / \mathrm{dL})\end{array}$ & $\begin{array}{c}\text { T-Bili } \\
\text { (mg/dL) }\end{array}$ & $\begin{array}{c}\text { T-Chol } \\
\text { (mg/dL) }\end{array}$ \\
\hline \multirow{3}{*}{$\begin{array}{c}\text { G1 } \\
0\end{array}$} & Mean & 30.3 & 91.4 & 297.9 & 0.90 & 158 & 12.7 & 0.48 & 0.05 & 84 \\
\hline & S.D. & 2.0 & 21.5 & 56.2 & 0.34 & 19 & 1.7 & 0.07 & 0.02 & 21 \\
\hline & $\mathrm{N}$ & 10 & 10 & 10 & $9^{\wedge}$ & 10 & 10 & 10 & 10 & 10 \\
\hline \multirow{3}{*}{$\begin{array}{l}\text { G2 } \\
800\end{array}$} & Mean & 29.8 & 79.8 & 289.5 & 0.64 & 174 & 13.0 & 0.47 & 0.05 & 99 \\
\hline & S.D. & 5.8 & 17.1 & 34.5 & 0.40 & 20 & 1.3 & 0.04 & 0.02 & 24 \\
\hline & $\mathrm{N}$ & 10 & 10 & 10 & $7^{\wedge}$ & 10 & 10 & 10 & 10 & 10 \\
\hline \multirow{3}{*}{$\begin{array}{c}\mathrm{G} 3 \\
2,000\end{array}$} & Mean & 27.7 & 77.5 & 308.5 & 0.89 & 168 & 13.0 & 0.48 & 0.05 & 92 \\
\hline & S.D. & 2.7 & 13.6 & 65.7 & 0.43 & 15 & 2.2 & 0.04 & 0.02 & 24 \\
\hline & $\mathrm{N}$ & 10 & 10 & 10 & $9^{\wedge}$ & 10 & 10 & 10 & 10 & 10 \\
\hline \multirow{3}{*}{$5, \quad$ G4 } & Mean & 28.7 & 85.5 & 266.8 & 1.03 & 165 & 12.9 & 0.50 & 0.05 & 81 \\
\hline & S.D. & 9.9 & 24.7 & 79.2 & 0.48 & 12 & 1.7 & 0.04 & 0.02 & 14 \\
\hline & $\mathrm{N}$ & 10 & 10 & 10 & $9^{\wedge}$ & 10 & 10 & 10 & 10 & 10 \\
\hline $\begin{array}{c}\text { Group } / \\
\text { Dose(mg/kg) }\end{array}$ & & $\begin{array}{c}\text { TG } \\
(\mathrm{mg} / \mathrm{dL})\end{array}$ & $\underset{(\mathrm{g} / \mathrm{dL})}{\mathrm{TP}}$ & $\begin{array}{c}\text { Alb } \\
(\mathrm{g} / \mathrm{dL})\end{array}$ & $\begin{array}{l}\mathrm{A} / \mathrm{G} \\
\text { ratio }\end{array}$ & $\begin{array}{c}\mathrm{P} \\
(\mathrm{mg} / \mathrm{dL})\end{array}$ & $\begin{array}{c}\mathrm{Ca} \\
(\mathrm{mg} / \mathrm{dL})\end{array}$ & $\begin{array}{c}\mathrm{Na} \\
(\mathrm{mmol} / \mathrm{L})\end{array}$ & $\begin{array}{c}\mathrm{K} \\
(\mathrm{mmol} / \mathrm{L})\end{array}$ & $\begin{array}{c}\mathrm{Cl} \\
(\mathrm{mmol} / \mathrm{L})\end{array}$ \\
\hline \multirow{3}{*}{$\begin{array}{c}\text { G1 } \\
0\end{array}$} & Mean & 75 & 6.2 & 2.5 & 0.69 & 5.95 & 10.4 & 141 & 4.5 & 104 \\
\hline & S.D. & 30 & 0.2 & 0.1 & 0.04 & 0.59 & 0.3 & 1 & 0.4 & 1 \\
\hline & $\mathrm{N}$ & 10 & 10 & 10 & 10 & 10 & 10 & 10 & 10 & 10 \\
\hline \multirow{3}{*}{$\begin{array}{l}\text { G2 } \\
800\end{array}$} & Mean & 75 & 6.2 & 2.5 & 0.66 & 6.05 & 10.4 & 141 & 4.6 & 104 \\
\hline & S.D. & 37 & 0.2 & 0.1 & 0.04 & 0.51 & 0.3 & 1 & 0.4 & 1 \\
\hline & $\mathrm{N}$ & 10 & 10 & 10 & 10 & 10 & 10 & 10 & 10 & 10 \\
\hline \multirow{3}{*}{$\begin{array}{c}\mathrm{G} 3 \\
2,000\end{array}$} & Mean & 96 & 6.2 & 2.5 & 0.69 & 5.76 & 10.5 & 141 & 4.6 & 104 \\
\hline & S.D. & 42 & 0.3 & 0.1 & 0.07 & 0.40 & 0.4 & 1 & 0.4 & 1 \\
\hline & $\mathrm{N}$ & 10 & 10 & 10 & 10 & 10 & 10 & 10 & 10 & 10 \\
\hline \multirow{3}{*}{$\begin{array}{c}\mathrm{G} 4 \\
5,000\end{array}$} & Mean & 72 & 6.2 & 2.4 & 0.65 & 6.14 & 10.5 & 140 & 4.7 & $103^{*}$ \\
\hline & S.D. & 27 & 0.3 & 0.1 & 0.04 & 0.33 & 0.3 & 1 & 0.5 & 1 \\
\hline & $\mathrm{N}$ & 10 & 10 & 10 & 10 & 10 & 10 & 10 & 10 & 10 \\
\hline \multicolumn{11}{|c|}{ Sex : Female } \\
\hline $\begin{array}{c}\text { Group } / / \\
\text { Dose(mg/kg) }\end{array}$ & & $\begin{array}{c}\mathrm{ALT} \\
(\mathrm{U} / \mathrm{L})\end{array}$ & $\begin{array}{l}\text { AST } \\
(\mathrm{U} / \mathrm{L})\end{array}$ & $\begin{array}{c}\mathrm{ALP} \\
(\mathrm{U} / \mathrm{L})\end{array}$ & $\begin{array}{l}\text { GGT } \\
(\mathrm{U} / \mathrm{L})\end{array}$ & $\begin{array}{c}\text { Glu } \\
(\mathrm{mg} / \mathrm{dL})\end{array}$ & $\begin{array}{c}\text { BUN } \\
(\mathrm{mg} / \mathrm{dL})\end{array}$ & $\begin{array}{c}\text { Crea } \\
\text { (mg/dL) }\end{array}$ & $\begin{array}{c}\text { T-Bili } \\
\text { (mg/dL) }\end{array}$ & $\begin{array}{c}\text { T-Chol } \\
\text { (mg/dL) }\end{array}$ \\
\hline \multirow{3}{*}{$\begin{array}{c}\text { G1 } \\
0\end{array}$} & Mean & 38.7 & 102.5 & 160.9 & 0.54 & 146 & 13.4 & 0.52 & 0.09 & 101 \\
\hline & S.D. & 36.1 & 83 & 65.0 & 0.37 & 12 & 1.3 & 0.06 & 0.02 & 22 \\
\hline & $\mathrm{N}$ & 10 & 10 & 10 & $8^{\wedge}$ & 10 & 10 & 10 & 10 & 10 \\
\hline \multirow{3}{*}{$\begin{array}{l}\text { G2 } \\
800\end{array}$} & Mean & 40.8 & 112.3 & 130.8 & 0.37 & 148 & 13.8 & 0.51 & 0.08 & 109 \\
\hline & S.D. & 20.0 & 43.9 & 43.7 & 0.28 & 15 & 2.2 & 0.06 & 0.01 & 21 \\
\hline & $\mathrm{N}$ & 10 & 10 & 10 & $6^{\wedge}$ & 10 & 10 & 10 & 10 & 10 \\
\hline \multirow{3}{*}{$\begin{array}{c}\mathrm{G} 3 \\
2,000\end{array}$} & Mean & 28.3 & 86.8 & 155.7 & 0.50 & 150 & 12.9 & 0.52 & 0.08 & 99 \\
\hline & S.D. & 13.8 & 21.3 & 53.9 & 0.23 & 13 & 1.4 & 0.05 & 0.02 & 17 \\
\hline & $\mathrm{N}$ & 10 & 10 & 10 & $6^{\wedge}$ & 10 & 10 & 10 & 10 & 10 \\
\hline \multirow{3}{*}{$\begin{array}{c}\mathrm{G} 4 \\
5,000\end{array}$} & Mean & 34.9 & 95.8 & 121.8 & 0.60 & 148 & 14.1 & 0.49 & 0.07 & 109 \\
\hline & S.D. & 20.9 & 42.4 & 45.8 & 0.32 & 20 & 2.8 & 0.07 & 0.01 & 25 \\
\hline & $\mathrm{N}$ & 10 & 10 & 10 & $6^{\wedge}$ & 10 & 10 & 10 & 10 & 10 \\
\hline $\begin{array}{c}\text { Group } / / \\
\text { Dose(mg/kg) }\end{array}$ & & $\begin{array}{c}\mathrm{TG} \\
(\mathrm{mg} / \mathrm{dL})\end{array}$ & $\mathrm{TP}_{(\mathrm{g} / \mathrm{dL})}$ & $\begin{array}{c}\text { Alb } \\
(\mathrm{g} / \mathrm{dL})\end{array}$ & $\begin{array}{l}\mathrm{A} / \mathrm{G} \\
\text { ratio }\end{array}$ & $\begin{array}{c}\mathrm{P} \\
(\mathrm{mg} / \mathrm{dL})\end{array}$ & $\begin{array}{c}\mathrm{Ca} \\
(\mathrm{mg} / \mathrm{dL}) \\
\end{array}$ & $\begin{array}{c}\mathrm{Na} \\
(\mathrm{mmol} / \mathrm{L})\end{array}$ & $\begin{array}{c}\mathrm{K} \\
(\mathrm{mmol} / \mathrm{L}) \\
\end{array}$ & $\begin{array}{c}\mathrm{Cl} \\
(\mathrm{mmol} / \mathrm{L})\end{array}$ \\
\hline \multirow{3}{*}{$\begin{array}{c}\text { G1 } \\
0\end{array}$} & Mean & 39 & 6.6 & 3.0 & 0.86 & 4.47 & 10.3 & 141 & 4.1 & 106 \\
\hline & S.D. & 38 & 0.4 & 0.3 & 0.08 & 0.54 & 0.4 & 1 & 0.2 & 1 \\
\hline & $\mathrm{N}$ & 10 & 10 & 10 & 10 & 10 & 10 & 10 & 10 & 10 \\
\hline \multirow{3}{*}{$\begin{array}{l}\text { G2 } \\
800\end{array}$} & Mean & 30 & 6.5 & 2.9 & 0.81 & 4.32 & 10.3 & 141 & 4.1 & 106 \\
\hline & S.D. & 16 & 0.4 & 0.2 & 0.05 & 0.89 & 0.4 & 1 & 0.3 & 2 \\
\hline & $\mathrm{N}$ & 10 & 10 & 10 & 10 & 10 & 10 & 10 & 10 & 10 \\
\hline \multirow{3}{*}{$\begin{array}{c}\mathrm{G} 3 \\
2,000\end{array}$} & Mean & 36 & 6.4 & 2.9 & 0.84 & 4.50 & 10.3 & 140 & 4.0 & 106 \\
\hline & S.D. & 26 & 0.3 & 0.2 & 0.07 & 0.71 & 0.3 & 1 & 0.2 & 2 \\
\hline & $\mathrm{N}$ & 10 & 10 & 10 & 10 & 10 & 10 & 10 & 10 & 10 \\
\hline & Mean & 57 & 6.8 & 3.1 & 0.84 & 5.09 & $10.7^{*}$ & 140 & 4.2 & $103^{* * *}$ \\
\hline $\begin{array}{c}\text { G4 } \\
5,000\end{array}$ & S.D. & 39 & 0.6 & 0.4 & 0.09 & 0.76 & 0.5 & 1 & 0.4 & 2 \\
\hline & $\mathrm{N}$ & 10 & 10 & 10 & 10 & 10 & 10 & 10 & 10 & 10 \\
\hline
\end{tabular}

$\wedge:$ Values below(above) the level of detection were excluded from statistics. Significantly different from control by Dunnett's t-test: * $\mathrm{p}<0.05,{ }^{* *} \mathrm{p}<0.01$. 
없었다. 그 외, 수컷 $5,000 \mathrm{mg} / \mathrm{kg}$ 투여군에서 부 분활성트롬보플라스틴시간(APTT)의 단축 및 암 컷 $5,000 \mathrm{mg} / \mathrm{kg}$ 투여군에서 백혈구백분율중의 산 호성 백혈구(EOS)의 감소가 관찰되었으나 경미 한 변동으로서 주시험에서 시험물질에 의한 영향 이 인정되지 않았으므로 독성학적 의미는 없다고 사료된다(Table 6).

\section{7. 혈액생화학적 검사}

주시험군의 암수 시험물질 투여군에서 시험물 질에 의한 영향으로 판단되는 결과는 없었다. 수 컷 $5,000 \mathrm{mg} / \mathrm{kg}$ 투여군에서 염소 $(\mathrm{Cl})$ 의 감소, 암 컷 $5,000 \mathrm{mg} / \mathrm{kg}$ 투여군에서 염소의 감소 및 칼슘 $(\mathrm{Ca})$ 의 증가가 관찰되었으나 모두 경미한 변동으 로 인(P), 나트륨 $(\mathrm{Na})$, 칼륨 $(\mathrm{K})$ 의 연관된 항목의 일정한 증가 또는 감소 경향도 동반되지 않았으 므로 독성학적 의미는 없다고 사료된다(Table 7).

회복군의 암수 $5,000 \mathrm{mg} / \mathrm{kg}$ 투여군에서 시험물 질에 의한 영향으로 판단되는 결과는 없었다. 그 외 암컷 $5,000 \mathrm{mg} / \mathrm{kg}$ 투여군에서 칼륨 $(\mathrm{K})$ 의 감소 가 관찰되었으나 주시험군에서 시험물질에 의한 영향이 인정되지 않았으며 비교적 경미한 변동으 로 독성학적 의미는 없다고 사료된다(Table 8).

\section{8. 장기중량}

주시험군의 암수 시험물질 투여군에서 시험물 질에 의한 영향으로 판단되는 결과는 없었다. 암 컷 $5,000 \mathrm{mg} / \mathrm{kg}$ 투여군에서 난소의 상대중량의 감소가 관찰되었으나 비교적 경미한 변동으로 생 물학적 변동범위(암컷 - ovary - relative: 0.0140 $0.0439 \mathrm{~g} / 100 \mathrm{~g}$ body weight) 내에 속하였으므로 독성학적 의미는 없다고 사료된다. 그 외 수컷 $800 \mathrm{mg} / \mathrm{kg}$ 투여군에서 뇌의 절대장기중량의 증가 가 관찰되었으나 용량의존성이 없었으므로 독성 학적 의미는 없다고 사료된다. 수컷 $5,000 \mathrm{mg} / \mathrm{kg}$ 투여군에서 간의 상대장기중량의 증가가 관찰되
었으나 용량증가에 따른 일정한 증가경향이 보이 지 않았으며, 암컷 $5,000 \mathrm{mg} / \mathrm{kg}$ 투여군에서 간의 절대장기중량의 증가가 관찰되었으나 상대장기 중량에서는 변화를 보이지 않았다. 그리고 간에 대한 형태학적 변화를 동반하지 않았으므로 독성 학적 의미는 없다고 사료된다.

회복군의 암수 $5,000 \mathrm{mg} / \mathrm{kg}$ 투여군에서 시험물 질에 의한 영향으로 판단되는 결과는 없었다. 암 컷 $5,000 \mathrm{mg} / \mathrm{kg}$ 투여군에서 난소의 절대 및 상대 중량의 증가가 관찰되었으나 비교적 경미한 변동 으로 생물학적 변동범위(암컷 - ovary-absolute : $0.0382 \sim 0.1001 \mathrm{~g}, \quad$ ovary - relative: $\quad 0.0115 \sim$ $0.0323 \mathrm{~g} / 100 \mathrm{~g}$ body weight) 내에 속하였으므로 독성학적 의미는 없다고 사료된다. 반면 대조군 에서 1마리에서는 난소 중량이 생물학적 변동범 위에 속하지 않았으나 부검결과 난소의 소형화가 동반하였으므로 장기중량이 감소된 것으로 판단 하였다. 그 외 수컷 $5,000 \mathrm{mg} / \mathrm{kg}$ 투여군에서 비장 의 절대장기중량의 증가가 관찰되었으나 상대장 기중량에서는 변화를 보이지 않았다.

\section{9. 부검}

주시험군의 암수 시험물질 투여군에서 시험물 질에 의한 영향으로 판단되는 결과는 없었다.

그 외 수컷 대조군에서 양측 앞발 피부에 가피 (crust)가 1례, 2,000 mg/kg 투여군에서 양측 고환 의 소형화(small)가 1 례, 암컷 대조군에서 좌측 신장에 암갈색의 변색부위(discolored area, dark brown)가 1례, $800 \mathrm{mg} / \mathrm{kg}$ 투여군에서 피하에 종 괴(mass)가 1례, 2,000 mg/kg 투여군에서 자궁에 암적색의 병소(focus, dark red)가 1례 관찰되었다. 회복군의 암수 $5,000 \mathrm{mg} / \mathrm{kg}$ 투여군에서 시험물질 에 의한 영향으로 판단되는 결과는 없었다. 그 외 암컷 대조군에서 좌측 난소의 소형화 및 꼬리의 인설(exfoliation)이 각 1례씩 관찰되었다(Table 9, 10). 
Table 8. Summary of Clinical Chemistry (Recovery group)

\begin{tabular}{|c|c|c|c|c|c|c|c|c|c|c|}
\hline \multicolumn{11}{|c|}{ Sex : Male } \\
\hline $\begin{array}{c}\text { Group / } \\
\text { Dose }(\mathrm{mg} / \mathrm{kg})\end{array}$ & & $\begin{array}{l}\text { ALT } \\
(\mathrm{U} / \mathrm{L})\end{array}$ & $\begin{array}{l}\mathrm{AST} \\
(\mathrm{U} / \mathrm{L})\end{array}$ & $\begin{array}{l}\text { ALP } \\
(\mathrm{U} / \mathrm{L})\end{array}$ & $\begin{array}{l}\text { GGT } \\
(\mathrm{U} / \mathrm{L})\end{array}$ & $\begin{array}{c}\text { Glu } \\
\text { (mg/dL) }\end{array}$ & $\begin{array}{c}\text { BUN } \\
(\mathrm{mg} / \mathrm{dL})\end{array}$ & $\begin{array}{c}\text { Crea } \\
(\mathrm{mg} / \mathrm{dL})\end{array}$ & $\begin{array}{c}\text { T-Bili } \\
\text { (mg/dL) }\end{array}$ & $\begin{array}{l}\text { T-Chol } \\
\text { (mg/dL) }\end{array}$ \\
\hline \multirow{3}{*}{$\begin{array}{c}\text { G1 } \\
0\end{array}$} & Mean & 29.1 & 84.1 & 226.2 & 0.55 & 154 & 13.1 & 0.45 & 0.06 & 94 \\
\hline & S.D. & 3.6 & 14.8 & 47.2 & 0.31 & 15 & 1.4 & 0.02 & 0.02 & 22 \\
\hline & $\mathrm{N}$ & 5 & 5 & 5 & 4 & 5 & 5 & 5 & 5 & 5 \\
\hline \multirow{3}{*}{$\begin{array}{c}G 4 \\
5,000\end{array}$} & Mean & 64.0 & 112.5 & 323.4 & 0.48 & 150 & 12.3 & 0.45 & 0.06 & 118 \\
\hline & S.D. & 80.6 & 96.9 & 95.3 & 0.22 & 13 & 1.1 & 0.07 & 0.02 & 47 \\
\hline & $\mathrm{N}$ & 5 & 5 & 5 & 5 & 5 & 5 & 5 & 5 & 5 \\
\hline $\begin{array}{c}\text { Group / } \\
\text { Dose }(\mathrm{mg} / \mathrm{kg})\end{array}$ & & $\begin{array}{c}\mathrm{TG} \\
(\mathrm{mg} / \mathrm{dL})\end{array}$ & $\begin{array}{c}\mathrm{TP} \\
(\mathrm{g} / \mathrm{dL})\end{array}$ & $\begin{array}{l}\text { Alb } \\
(\mathrm{g} / \mathrm{dL})\end{array}$ & A/G ratio & $\underset{(\mathrm{mg} / \mathrm{dL})}{\mathrm{P}}$ & $\begin{array}{c}\mathrm{Ca} \\
(\mathrm{mg} / \mathrm{dL})\end{array}$ & $\underset{(\mathrm{mmol} / \mathrm{L})}{\mathrm{Na}}$ & $\begin{array}{c}\mathrm{K} \\
(\mathrm{mmol} / \mathrm{L})\end{array}$ & $\begin{array}{c}\mathrm{Cl} \\
(\mathrm{mmol} / \mathrm{L})\end{array}$ \\
\hline \multirow{3}{*}{$\begin{array}{c}\text { G1 } \\
0\end{array}$} & Mean & 75 & 6.1 & 2.4 & 0.67 & 5.39 & 10.3 & 140 & 4.5 & 104 \\
\hline & S.D. & 14 & 0.2 & 0.1 & 0.04 & 0.34 & 0.2 & 2 & 0.3 & 2 \\
\hline & $\mathrm{N}$ & 5 & 5 & 5 & 5 & 5 & 5 & 5 & 5 & 5 \\
\hline \multirow{3}{*}{$\begin{array}{c}\text { G4 } \\
5,000\end{array}$} & Mean & 93 & 6.2 & 2.5 & 0.68 & 5.63 & 10.4 & 140 & 4.5 & 104 \\
\hline & S.D. & 3.5 & 0.3 & 0.2 & 0.04 & 0.40 & 0.4 & 1 & 0.3 & 1 \\
\hline & $\mathrm{N}$ & 5 & 5 & 5 & 5 & 5 & 5 & 5 & 5 & 5 \\
\hline \multicolumn{11}{|c|}{ Sex : Female } \\
\hline $\begin{array}{c}\text { Group / } \\
\text { Dose }(\mathrm{mg} / \mathrm{kg})\end{array}$ & & $\begin{array}{l}\text { ALT } \\
(\mathrm{U} / \mathrm{L})\end{array}$ & $\begin{array}{l}\text { AST } \\
(\mathrm{U} / \mathrm{L})\end{array}$ & $\begin{array}{l}\text { ALP } \\
(\mathrm{U} / \mathrm{L})\end{array}$ & $\begin{array}{l}\text { GGT } \\
(\mathrm{U} / \mathrm{L})\end{array}$ & $\begin{array}{c}\text { Glu } \\
(\mathrm{mg} / \mathrm{dL})\end{array}$ & $\begin{array}{c}\text { BUN } \\
(\mathrm{mg} / \mathrm{dL})\end{array}$ & $\begin{array}{c}\text { Crea } \\
(\mathrm{mg} / \mathrm{dL})\end{array}$ & $\begin{array}{c}\text { T-Bili } \\
\text { (mg/dL) }\end{array}$ & $\begin{array}{l}\text { T-Chol } \\
(\mathrm{mg} / \mathrm{dL})\end{array}$ \\
\hline \multirow{3}{*}{$\begin{array}{c}\text { G1 } \\
0\end{array}$} & Mean & 40.4 & 106.9 & 115.7 & 0.27 & 148 & 15.5 & 0.48 & 0.12 & 117 \\
\hline & S.D. & 9.6 & 33.2 & 41.9 & 0.36 & 17 & 2.2 & 0.09 & 0.03 & 41 \\
\hline & $\mathrm{N}$ & 5 & 5 & 5 & 2 & 5 & 5 & 5 & 5 & 5 \\
\hline \multirow{3}{*}{$\begin{array}{c}\text { G4 } \\
5,000\end{array}$} & Mean & 33.2 & 78.9 & 128.8 & 0.44 & 153 & 13.3 & 0.48 & 0.11 & 114 \\
\hline & S.D. & 8.8 & 23.6 & 48.5 & 0.02 & 10 & 1.5 & 0.07 & 0.04 & 35 \\
\hline & $\mathrm{N}$ & 5 & 5 & 5 & 2 & 5 & 5 & 5 & 5 & 5 \\
\hline $\begin{array}{c}\text { Group / } \\
\text { Dose(mg/kg) }\end{array}$ & & $\begin{array}{c}\mathrm{TG} \\
(\mathrm{mg} / \mathrm{dL})\end{array}$ & $\underset{(\mathrm{g} / \mathrm{dL})}{\mathrm{TP}}$ & $\begin{array}{l}\mathrm{Alb} \\
(\mathrm{g} / \mathrm{dL})\end{array}$ & $\mathrm{A} / \mathrm{G}$ ratio & $\begin{array}{c}\mathrm{P} \\
(\mathrm{mg} / \mathrm{dL})\end{array}$ & $\begin{array}{c}\mathrm{Ca} \\
(\mathrm{mg} / \mathrm{dL})\end{array}$ & $\begin{array}{c}\mathrm{Na} \\
(\mathrm{mmol} / \mathrm{L})\end{array}$ & $\begin{array}{c}\mathrm{K} \\
(\mathrm{mmol} / \mathrm{L})\end{array}$ & $\begin{array}{c}\mathrm{Cl} \\
(\mathrm{mmol} / \mathrm{L})\end{array}$ \\
\hline \multirow{3}{*}{$\begin{array}{c}\text { G1 } \\
0\end{array}$} & Mean & 46 & 6.6 & 3.0 & 0.82 & 4.22 & 10.4 & 140 & 4.2 & 103 \\
\hline & S.D. & 22 & 0.6 & 0.4 & 0.07 & 0.60 & 0.5 & 1 & 0.3 & 2 \\
\hline & $\mathrm{N}$ & 5 & 5 & 5 & 5 & 5 & 5 & 5 & 5 & 5 \\
\hline \multirow{3}{*}{$\begin{array}{c}\text { G4 } \\
5,000\end{array}$} & Mean & 95 & 6.6 & 3.0 & 0.86 & 4.37 & 10.4 & 140 & $3.9^{*}$ & 103 \\
\hline & S.D. & 48 & 0.6 & 0.4 & 0.09 & 0.39 & 0.5 & 1 & 0.1 & 1 \\
\hline & $\mathrm{N}$ & 5 & 5 & 5 & 5 & 5 & 5 & 5 & 5 & 5 \\
\hline
\end{tabular}

Significantly different from control by Dunnett's t-test: * $p<0.05$.

\section{0. 조직병리학적 검사}

주시험군의 암수 시험물질 투여군에서 시험물 질에 의한 영향으로 판단되는 결과는 없었다. 암 컷 $5,000 \mathrm{mg} / \mathrm{kg}$ 투여군의 난소에서 난소낭을 동
반한 위축(atrophy with cystic follicles) 소견이 미미하게 2례 관찰되었는데 난소의 장기중량의 감소와 연관성이 있었다. 그러나 2개체를 제외한 난소에서는 그러한 변화가 인정되지 않은 
Table 9. Summary of Necropsy Findings (Maingroup)

\begin{tabular}{|c|c|c|c|c|c|c|c|c|c|}
\hline \multirow[b]{2}{*}{ Organ / } & \multirow[b]{2}{*}{ Group } & \multicolumn{4}{|c|}{ Male } & \multicolumn{4}{|c|}{ Female } \\
\hline & & G1 & G2 & G3 & G4 & G1 & G2 & G3 & G4 \\
\hline \multirow[t]{4}{*}{ Findings } & Dose $(\mathrm{mg} / \mathrm{kg})$ & 0 & 800 & 2,000 & 5,000 & 0 & 800 & 2,000 & 5,000 \\
\hline & No. of animals & 10 & 10 & 10 & 10 & 10 & 10 & 10 & 10 \\
\hline & Unremarkable findings & 9 & 10 & 9 & 10 & 9 & 9 & 9 & 10 \\
\hline & No. of examined & 10 & 10 & 10 & 10 & 10 & 10 & 10 & 10 \\
\hline Kidney & -Discolored area, dark brown, left & 0 & 0 & 0 & 0 & 1 & 0 & 0 & 0 \\
\hline \multirow{2}{*}{ Skin } & -Crust, right and left forelimb & 1 & 0 & 0 & 0 & 0 & 0 & 0 & 0 \\
\hline & -Mass, subcutaneus & 0 & 0 & 0 & 0 & 0 & 1 & 0 & 0 \\
\hline Testis & -Small, bilateral & 0 & 0 & 1 & 0 & & & & \\
\hline Uterus & -Focus, dark red & & & & & 0 & 0 & 1 & 0 \\
\hline
\end{tabular}

External surface and other organs in body cavity (cranial, thoracic and abdominal) were unremarkable.

Table 10. Summary of Necropsy Findings (Recoverygroup)

\begin{tabular}{clcccc}
\hline \multirow{3}{*}{ Organ / Findings } & Sex & Male & \multicolumn{2}{c}{ Female } \\
\cline { 2 - 6 } & Group & G1 & G4 & G1 & G4 \\
& Dose (mg/kg) & 0 & 5,000 & 0 & 5,000 \\
& No. of animals & 5 & 5 & 5 & 5 \\
\hline \multirow{2}{*}{ Onary } & Unremarkable findings & 5 & 5 & 3 & 5 \\
Tail & No. of examined & 5 & 5 & 5 & 5 \\
& -Small, left & & & 1 & 0 \\
\hline
\end{tabular}

External surface and other organs in body cavity (cranial, thoracic and abdominal) were unremarkable.

반면 암컷 $800 \mathrm{mg} / \mathrm{kg}$ 투여군의 난소에서 경도의 난소낭을 동반한 위축이 1 례 관찰되었으므로 시 험물질 투여에 의한 일정한 증가경향이나 정도 (severity)의 경향이 보이지 않아 시험물질과의 관련성은 찾을 수 없었다. 난소의 위축소견은 $\mathrm{SD}$ 랫드에서 가령성 소견으로 흔히 알려져 있으므로 우발적 분포에 기인한 변화로서 독성학적 의미는 없다고 사료된다. 부검 시 관찰된 소견에 대한 조 직병리학적 검사 결과 수컷 대조군에서의 앞발 피부의 가피는 표피의 비후를 동반한 가피(crust, with thickening), $2,000 \mathrm{mg} / \mathrm{kg}$ 투여군에서의 양 측 고환의 소형화는 위축(atrophy), 암컷 800 $\mathrm{mg} / \mathrm{kg}$ 투여군에서의 피하 종괴는 유선의 선암종 (adenocarcinoma), 2,000 mg/kg 투여군에서의 자
궁의 암적색 병소는 혈종(hematoma)으로 확인되 었으나 모두 단 1 례씩으로서 자연발생적이거나, 우발적으로 분포하였으므로 독성학적 의미는 없 다고 사료된다. 암컷 대조군에서의 좌측 신장의 암갈색의 변색부위는 형태학적 변화가 관찰되지 않았다. 그 외 암수 대조군 및 $5,000 \mathrm{mg} / \mathrm{kg}$ 투여 군에서 부고환, 안구, 하더리안선, 심장, 신장, 간, 폐 및 기관지, 췌장, 뇌하수체, 전립선, 갑상선에 서 관찰된 소견은 모두 자연발생성으로서 해당 주령의 $\mathrm{SD}$ 랫드에서 흔히 관찰되는 병변으로 우 발적 또는 산발적으로 분포하였으므로 모두 독성 학적인 의미는 없다고 사료된다.

회복군의 암수 $5,000 \mathrm{mg} / \mathrm{kg}$ 투여군에서 시험물 질에 의한 영향으로 판단되는 결과는 없었다. 암 
컷 $5,000 \mathrm{mg} / \mathrm{kg}$ 투여군에서 경도의 난소의 위축 소견이 1 례 관찰된 반면 대조군에서 경도로 2례 가 관찰되었다. 주시험군 및 회복시험에서 연속 적으로 관찰된 난소의 위축소견의 발생례에서 시 험물질 투여와의 명확한 연관성은 보이지 않았 다. 따라서 난소의 위축소견은 모두 우발적 분포 에 따른 것으로서 독성학적 의미는 없다고 사료 된다. 부검 시 관찰된 소견에 대한 조직병리학적 검사 결과, 암컷 대조군에서의 좌측 난소의 소형 화는 난포낭, 꼬리의 인설은 각화과다증 (hyperkeratosis)으로 확인되었으나 모두 대조군 에서 관찰된례로서 독성학적 의미는 없다고 사료 된다. 그 외 암수 대조군 및 $5,000 \mathrm{mg} / \mathrm{kg}$ 투여군 에서 하더리안선, 심장, 신장, 간, 폐 및 기관지, 난소, 췌장, 뇌하수체, 갑상선에서 관찰된 소견은 모두 자연발생성으로서 해당 주령의 $\mathrm{SD}$ 랫드에 서 흔히 관찰되는 병변으로 우발적 또는 산발적 으로 분포하였으므로 모두 독성학적인 의미는 없 다고 사료된다.

\section{IV. 고찰}

치매는 만성, 진행성 뇌질환과 같은 병적인 노 화로 기억력, 사고력, 지남력, 이해, 학습, 판단 등 다수의 고위대뇌기능장애로 정의할 수 있다 ${ }^{20)}$. 우리나라 65 세 이상 노인인구의 약 $8.3 \%$ 인 31만 명 정도가 치매노인으로 추정되며 80세 이상 노 인인구에서는 약 $25 \%$ 정도로 추정된다 ${ }^{21)}$.

$\mathrm{AD}$ 의 주요 병리학적 소견은 신경섬유 덩어리 (neurofibrillary tangle)와 신경반(neuritic plaque) 으로 ${ }^{22)}$, 신경반은 아밀로이드 전구단백질(amyloid precursor protein; APP)로 알려진 큰 막단백질의 가수분해에 의해 생긴 $4 \mathrm{kDa} \mathrm{A \beta}$ peptide로 구성되 어 있으며 ${ }^{23)}$ 축적된 $\mathrm{A} \beta$ peptide는 주변 세포들에 염증반응을 일으켜 신경세포가 손상되고 뇌의 정 상적인 기능을 유지하는 신경회로망을 훼손한다 ${ }^{24)}$.
현재 $\mathrm{AD}$ 의 원인과 병리기전을 밝히기 위한 연 구는 진행 중이며 아직 명확한 원인과 치료약물 은 없는 상황이다. 이에 본 연구팀은 보건복지부 한의약선도기술개발사업의 지원을 받아 치매치 료 한방신약 $\mathrm{ACM}$ 개발 연구를 진행하였다.

$\mathrm{ACM}$ 은 白获神, 遠志, 石菖蒲로 이루어진 聰明 湯에 山䍒肉, 巴戟天을 가미한 처방으로 이전의 연구에서 遠志는 microglial cells에서 염증성 매 개인자 억제를 통하여 퇴행성 신경 질환의 치료 에 효능이 있고 ${ }^{25}$, 遠志, 石菖蒲, 聰明湯 추출물은 각각 $\mathrm{MAP} 2$ 와 MAP-Tau 단백질의 조절 기전에 관 여하여 신경세포 손상에 방어작용이 있음 ${ }^{26)}$ 이 보 고되었다. 또한 다양한 聰明湯加味方이 치매 치 료에 효과적으로 활용 될 수 있다는 다수의 연구 결과가 발표되었다 ${ }^{9-13)}$. 巴戟天이 항콜린작용과 APP와 PS-1, PS-2 발현 억제능력을 가져 치매 치 료에 활용될 수 있다는 연구 결과와 ${ }^{15)}$ 山査肉이 IL-1 $\beta$, IL-6, APP, AChE,gFAP mRNA, TNF- $a$ 의 발현을 억제하고 ROS, NO의 생성을 억제하여 치 매 치료에 활용될 수 있다는 연구 결과 ${ }^{16)}$, 山查聰 明湯 ${ }^{17)}$ 과 巴韩天聰明湯 ${ }^{18)}$ 의 항염증효과, 기억력 감퇴 억제 효과, 뇌세포 보호효과, 행동개선효과 로 치매 치료에 활용될 수 있다는 연구 결과, 聰 明湯에 巴戟天, 山查肉을 가한 聰明湯加味方이 $\mathrm{BACE}$ 효소활성과 $\mathrm{BA}$ 의 과다 생성을 억제하여 치매 치료에 효과가 있다는 연구 결과 ${ }^{19)}$ 등이 보 고되었다. 본 연구팀은 이러한 연구 결과들을 근 거로 $\mathrm{ACM}$ 을 연구개발 중이며, 연구의 일환으로 $\mathrm{ACM}$ 의 안전성을 평가하기 위하여GLP기관인 바 이오톡스텍(주)에 의뢰하여 $\mathrm{ACM}$ 의 rat를 이용한 13 주 반복 경구투여 독성시험 및 4주 회복시험을 진행하였다.

$\mathrm{ACM}$ 의 rat를 이용한 단회 경구투여 독성시험 결과 암수 $5000 \mathrm{mg} / \mathrm{kg}$ 투여군의 체중 및 부검에 서 시험물질 투여에 의한 영향은 인정되지 않아 치사량은 암수 각 $5000 \mathrm{mg} / \mathrm{kg}$ 을 상회하는 것으로 판단되었고 ${ }^{27)}$, 4 주 반복 경구투여 용량결정시험 
결과 암수 $5000 \mathrm{mg} / \mathrm{kg}$ 투여군에서 시험물질에 기 인한 독성변화는 인정되지 않았다. 따라서 13 주 반복투여 독성시험의 고용량은 $5000 \mathrm{mg} / \mathrm{kg}$, 저용 량은 $1000 \mathrm{mg} / \mathrm{kg}$ 이하로 설정하였다.

총명탕가감 한방신약 ACM을 Sprague-Dawley $(\mathrm{Crl}: \mathrm{CD}(\mathrm{SD}))$ 계 암수 랫드에 13 주간 반복투여시 에 대한 안전성을 평가하고자한 본 시험에서 시 험물질은 $800,2,000$ 및 $5,000 \mathrm{mg} / \mathrm{kg}$ 의 3 개의 용량으로 암수 각각 군당 10,10 및 15 마리에 13 주간 경구 투여하였다. 또한 대조군(주사용수)을 설정하여 군당 15 마리에 13 주간 경구 투여하였 다. 대조군 및 $5,000 \mathrm{mg} / \mathrm{kg}$ 투여군에는 암수 각 5 마리씩 독성의 가역성을 평가하기 위해 4 주간 의 회복기간을 두었다. 관찰기간동안 일반증상관 찰, 체중측정, 사료섭취량 측정, 안과학적 검사, 뇨검사를 실시하였고, 관찰기간 종료 후 혈액 및 혈액생화학적 검사, 장기의 중량측정, 부검 시 육 안적 검사 및 조직병리학적 검사를 수행하였다. 관찰기간동안 암수 시험물질 투여군에서 사망례 는 관찰되지 않았다. 주시험군 및 회복군 일부에 서 뇨검사, 혈액학적 검사, 혈액생화학적 검사, 장기중량, 조직병리학적 검사 등에서 변화가 관 찰되었으나, 모두 경미한 변동인점, 생물학적 변 동범위 이내인점, 용량의존성이 없는점, 장기의 형태학적 변화가 관찰되지 않은점, 대조군에서도 관찰된점, $\mathrm{SD}$ 랫드에서 흔히 관찰되는 병변으로 우발적 또는 산발적으로 분포한점 등을 근거로 독성학적 의미는 없다고 사료된다.

투여기간동안 암수 시험물질 투여군에서 약물 혼입변이 관찰되었고, 암수 $5,000 \mathrm{mg} / \mathrm{kg}$ 투여군에 서 회복 2 3 일까지 관찰된 후 관찰되지 않았다. 체중, 사료섭취량, 안과학적 검사, 뇨검사, 혈액학 적 검사, 혈액생화학적 검사, 장기중량 및 부검에 있어서, 암수 시험물질 투여군에서 시험물질 투여 에 기인한 독성변화는 관찰되지 않았다. 조직병리 학적 검사결과, 암수 $5,000 \mathrm{mg} / \mathrm{kg}$ 투여군에서 시험 물질 투여에 기인한 독성변화는 관찰되지 않았다.

\section{V. 결론}

이상으로 본 시험 조건 하에서의 치매치료 한 방신약 개발을 위한 총명탕가감 $\mathrm{ACM}$ 에 대한 암 수 랫드를 이용한 13 주 경구 반복투여 독성시험, 4 주 회복시험을 실시한 결과, 암수 $5,000 \mathrm{mg} / \mathrm{kg}$ 용량에서 독성변화가 관찰되지 않아 무독성량 (NOAEL)은 암수 모두 $5,000 \mathrm{mg} / \mathrm{kg}$ 을 상회하는 것으로 판단된다.

\section{References}

1. The Korean society of oriental neuropsychiatry. Oriental neuropsychiatry. Seoul:Jipmundang. 2007:324-33.

2. Oide T, Kinoshita T, Arima K. Regression stage senile plaques in the natural course of alzheimer's disease. Neuropathology appl neurobiology. 2006;32(5):539-56.

3. Sinha S, Anderson JP, Barbour R, BasigS, Caccavello R, Davis D, et al. Purification and cloning of amyloid precursor protein beta-secretase from human brain. Nature. 1999;402:537-40.

4. McGrath LT. Increased oxidative stress in alzheimer's disease as assessed with 4-hydroxynonenal but not malondialdehyde. Q J medicin. 2001;94:485-90.

5. David S. Treatmentguidelines for alzheimer's disease - redefinding perceptions in primary care. Primary care companion J clinic psychiatry. 2007;9(2):113-21.

6. Cheng, Chen KS, Knox J, Inglis J, Bernard A, Martin SJ, et al. A learning deficit related to age and beta-amyloid plaques in a mouse model of Alzheimer' disease. Nature. 
2000;408:975 - 9 .

7. Heo J. Dongeuibogam. Seoul : Dongeuibogam publisher. 2005:98-100.

8. Lee SI. Clinical applications of herbal medicine. Seoul:Seongbosa. 1990:151-3, 308-13, 419-20, 426-8.

9. Kim YW, Song TW, Oh MS. Effect of Chongmyungtang on learning and memory in normal and scopolamine-induced amnestic mice. Journal of Oriental Rehabilitation Medicine. 1998;8(2):464-79.

10. Lim JH, Lee SR. The Effects of PalMihapChongMungTang(PMCMT) hot water extract \& ultra-fine powder on the Alzheimer's disease model. Journal of oriental neuropsychiatry. 2008;19(2):95-110.

11. Kim HJ, Lee SR. The Effects of KakamBoyangHwanoh-Tang(KBHT) and PalMihapChongMung-Tang(PMCMT) on protecting microglia and inhibiting acetylcholinesterase and oxidants. Journal of oriental neuropsychiatry. 2008;19(2):65-75.

12. Lee SH, Jung IC, Lee SR. Effect of KwyBiChongMung-Tang hot water extract \& ultra-fine powder on the Alzheimer's disease model. Korean journal of oriental physiology \& pathology. 2007;21(4):921-33.

13. Choi KW, Lee SR, Jung IC. Effects of ChongMyung-Tang and ChongMyung-Tang added Hibiscus syriacus hot water extract \& ultra-fine powder on microglia and memory deficit model. Journal of oriental neuropsychiatry. 2006;20(2):1200-10.

14. Department of the national association of Herbalogy. Herbalogy. Seoul:Youngrimsa. 2008:411-2,594-5.

15. Kim HS, Jung IC, Lee SR. Effects of
Morinda officinalis(MDOF) on inhibition of impairment of learning and memory, and acetylcholinesterase in amnesia mice. Journal of oriental neuropsychiatry. 2003; 14(1):45-58.

16. Chae JG, Jung IC, Lee SR. The effects of Crataegus prinnatiflora BGE. var. major N.E. BR(CPVM) extract on the the Alzheimer's disease model induced by CT105. Journal of oriental neuropsychiatry. 2002;13(1):79-115.

17. Ha SY, Jung IC, Lee SR. The effects of ChongMyungTang(CMT) and SanSaChongMyungTang (SCMT) on the Alzheimer`s disease model. Journal of oriental neuropsychiatry. 2006; 17(1):59-78.

18. Lim JH, Jung IC, Lee SR. The effects of ChongMyungTang(CMT) and ChongMyungTang added Moutan Cortex(PCMT) hot water extract \& ultra-fine powder on microglia and memory deficit model. Korean journal of oriental physiology \& pathology. 2006;20(4): 997-1008.

19. Lim JH, Jung IC, Lim JS, Kim SH, Lee SR. Effect of Chongmyung-Tang prescription combination on the production of amyloid $\beta$ protein and $\beta$-site amyloid precursor protein-cleaving enzyme activity in vitro. Journal of oriental neuropsychiatry. 2010; 21(2):191-200.

20. Lee KW. Clinical neurology. Seoul: Beommunsa. 2003:203-15.

21. Byeon YC. The mapping development research of dementia management. Korea Institute for Health and Social Affairs. 1997.

22. Citron M, Diehl TS,gordong, Biere AL, Seubert P, Selkoe DJ. Evidence that the 42- 
and 40-amino acid forms of amyloid beta protein aregenerated from the beta-amyloid precursor protein by different protease activities. Proc. Natl. Acad. Sci. USA. 1996;93:13170 - 5.

23. John V, Beck JP, Bienkowski MJ, Sinha S, Heinrikson RL. Human beta-secretase (BACE) and BACE inhibitors. J. Med. Chem. 2003;46(22):4625-30.

24. Je JY, Kim SK. Water-soluble chitosan derivatives as a BACE1 inhibitor. Bioorg. Med. Chem. Lett. 2005;13:6551-5.

25. Cheong MH, Lee SR, Yoo HS, Jeong JW, KimgY, Kim WJ, Jung IC, Choi YH. Anti-inflammatory effects of Polygala tenuifolia root through inhibition of NF- $\mathrm{KB}$ activation in lipopolysaccharide-induced BV2 microglial cells. Journal of ethnopharmacology. 2011;137(3):1402-8.

26. Park EK, Shim ES, Jung HS, Sohn NW, Sohn YJ. Effects of chongmyung-tang, polygalae radix and acorigraminei rhizoma on $\mathrm{A} \beta$ toxicity and memory dysfunction in mice. Korean J. Orient. Int. Med. 2008;29(3):608-20.

27. Choi WC, Jung IC, Lim JS, Kim SH, Lee SR. Single oral dose toxicity test of ACM(Added Chongmyung-tang) in Sprague-Dawley rat. Journal of oriental neuropsychiatry. 2012; 23(2):121-8. 